\title{
SELAGHIAN TRADITIONAL SANCTIONS UPON A PERSPECTIVE OF ISLAMIC LAW (Study on Serawai Community in Air Nipis District, South Bengkulu Regency)
}

\author{
Tendra Hernata ${ }^{1}$, Toha Andiko ${ }^{2}$ \\ 1,2Postgraduate at UIN Fatmawati Sukarno Bengkulu \\ Jl. Raden Fatah Pagar Dewa Bengkulu \\ Email: ${ }^{1}$ tendraharnata384@gmail.com, ${ }^{2}$ toha.andiko@gmail.com
}

\begin{abstract}
This study discusses the issue of the application of selaghian customary sanctions to the Serawai people of South Bengkulu as well as examines the opinion of Islamic law on these sanctions. This study uses a qualitative method with a descriptive normative legal approach, to unravel the facts found in the field (field research). Based on the data collected through observation and in-depth interviews in the field, it was found that the form of selaghian that is still being practiced is selaghian sebambangan, a type of selaghian performed by a couple (male and female) with both of them secretly running away from the house with no friends, going to the house of a local traditional leader, then being told by someone else to tell the couple's parents, to pick up the couple and marry them off. Customs impose fines that vary according to the severity of the offense committed. In terms of Islamic law, the provision of customary sanctions in the form of tazir punishment is legal and may be carried out as a good custom (urf shahih) with the aim of causing a deterrent effect for the perpetrators (zawajir).
\end{abstract}

Keywords: Selaghian; Serawai Tribe; Islamic Law

\begin{abstract}
Abstrak: Penelitian ini membahas persoalan tentang penerapan sanksi adat selaghian pada masyarakat Serawai Bengkulu Selatan sekaligus mengkaji tentang pendapat hukum Islam terhadap sanksi tersebut. Penelitian ini menggunakan metode kualitatif dengan pendekatan hukum normatif yang bersifat deskriptif, untuk mengurai fakta-fakta yang ditemukan di lapangan (field research). Berdasarkan data-data yang dikumpulkan melalui observasi dan wawancara mendalam di lapangan, ditemukan fakta bahwa bentuk selaghian yang masih dipraktikkan adalah selaghian sebambangan, jenis selaghian yang dilakukan oleh pasangan (laki-laki dan perempuan) dengan keduanya secara sembunyi melarikan diri dari rumah dengan tidak membawa teman, menuju rumah tokoh adat setempat, lalu disuruh orang lain untuk memberitahu orang tua pasangan tersebut, agar menjeput pasangan itu dan menikahkannya. Adat menjatuhkan denda yang bervariasi sesuai dengan berat ringannya pelanggaran yang dilakukan. Dalam tinjauan hukum Islam, pemberian sanksi adat selaghian berupa hukuman ta'zir adalah sah dan boleh dilakukan sebagai suatu adat kebiasaan yang baik (urf shahih) dengan tujuan untuk menimbulkan efek jera bagi pelakunya (zawajir).
\end{abstract}

Kata kunci: Selaghian; Suku Serawai; Hukum Islam 


\section{Introduction}

Indonesian society is a heterogeneous society that has many tribes, cultures, customs and so on. One of these indigenous peoples who are still implementing the customary sanction system is the Serawai tribal community in Air Nipis District, South Bengkulu Regency. Among the customary sanctions that are still being applied are the customary sanctions of selaghian (elopement), while Islamic teachings do not recognize the term selaghian. Based on the customary law of the institution that was collected and rewritten by Kiagus Husein, what Selaghian meant was "the going of a woman to the place of a man she already knows with the aim of getting married". ${ }^{1}$ In this customary law selaghian divided into two namely, selaghian maling diri and sebambangan. Selaghian maling diri namely, men and women who selaghian each brought two friends, the male brought two male friends and the female brought two female friends. Whereas selaghian sebambangan namely, men and women who selaghian each of them does not bring friends. ${ }^{2}$

For people who practice selaghian they get customary sanctions, as for the sanctions, namely: selaghian self-stealing if the victim is a girl then a fine of $f 12,00^{3}$, if the widow is $f 6,00$, if the fiancé is $f 24,00$. As for those who do selaghian sebambangan fined as much as a girl $f 24,00$., if a widow is $f 12,00$, if a fiancé is $f 48,00 .{ }^{4}$

The customary sanctions applied now no longer use currency of florin but converted

${ }^{1} \mathrm{Ki}$ Agoes Hosen, Kumpulan Undang-Undang Adat Lembaga dari Sembilan Onderafdelingen dalam Keresidenan Bengkulu, (Jakarta: Proyek Penerbitan Buku Bacaan Sastra Indonesia dan Daerah, 1985), p. 89.

${ }^{2} \mathrm{Ki}$ Agoes Hosen, Kumpulan Undang-Undang...,p. 89

${ }^{3} f$ (Florin), adalah jenis mata uang yang berlaku saat aturan ini diberlakukan yaitu pada tahun 1913, $f 1=1$ real.

${ }^{4} \mathrm{Ki}$ Agoes Hosen, Kumpulan Undang-Undang...,p. 90. to rupiah. It is $\mathrm{Rp} 250.000,00$ if a virgin, $\mathrm{Rp}$ $100.000,00$ if a widow, Rp 500.000,00 if a one's fiancé, Rp 250.000,00 if a one's widow. ${ }^{5}$ This can be proven by a case involving a male partner having his address at Suka Negeri Village (17 years old) and a woman having his address at Desa Maras (16 years old) who always goes to a male parent's house in Suka Negeri Village. They were always in December 2019, in this case the men and women were each given customary sanctions with a monetary fine of Rp. 250,000.00 each. The fine is paid to the village head when taking care of the marriage administration requirements. The distribution of the fine money is divided into three parts, partly for the village head, partly for the hamlet head (Kadun), and partly going into the village treasury. ${ }^{6}$ From searching the data, the researcher did not find a strong legal reason for the village head to withdraw the money. It is not contained in village regulations (Perdes) or other regulations. It's just that the reason that emphasizes village heads in withdrawing the money is to implement existing customs. If this is not implemented, it will get a warning from traditional elders in the local area. ${ }^{7}$

This means that the process of imposing sanctions on the perpetrators of selaghian in Air Nipis District, South Bengkulu Regency, it is not through customary deliberations as is generally done when imposing sanctions for someone's wrongdoing. ${ }^{8}$ While Islamic law outlines long and strict provisions before

\footnotetext{
${ }^{5}$ Personal Interview with Sairi (Chairman of BMA Air Nipis District), Air Nipis, 15 November 2020.

${ }^{6}$ Personal Interview with Sairi (Chairman of BMA Air Nipis District), Air Nipis, 15 November 2020

${ }^{7}$ Personal Interview with Sairi (Chairman of BMA Air Nipis District), Air Nipis, 15 November 2020

${ }^{8}$ Personal Interview with Sairi (Chairman of BMA Air Nipis District), Air Nipis, 15 November 2020
} 
imposing punishment, for example in cases of adultery. ${ }^{9}$

Number of cases of selaghian in Air Nipis District in 2019, according to the head of the District BMA, which was around 17 cases. As for most of the age of men and women who selaghian are around the age of 15 to 18 years. Their reason of selaghian generally caused by pregnancy out of wedlock, promiscuity, and to realize the desire to marry that has not been approved by parents. ${ }^{10}$ So based on this phenomenon, the application of customary sanctions of selaghian the Serawai tribal community in Air Nipis District above has not achieved the expected sanctions goal, both according to the purpose of sanctions in Islamic law, even according to custom itself. This can be indicated by the large number selaghian cases, perpetrator's age of selaghian are under age $^{11}$, and with light sanctions, teenagers can use it as a tool to force their parents (guardians) to marry them off.

Among the objectives of imposing sanctions in Islamic law is to provide a deterrent effect for perpetrators and the community (zawajir). This means that with the provision of sanctions, the local people (community) will not do that act again. But the fact is that based on the number of cases above, the Serawai Tribe community in Air Nipis District in particular, is still doing it selaghian although there have been sanctions given.

Based on the description of the background above, what is used as the main problem in this research is how to apply customary sanctions

${ }^{9}$ Hilman, Hukum Pidana Syariat Islam Menurut Ajaran Ahlus Sunnah, (Jakarta: Bulan Bintang, 1970), h. 399.

${ }_{10}$ Personal Interview with Sairi (Chairman of BMA Air Nipis District), Air Nipis, 15 November 2020

${ }^{11}$ State Gazette of the Republic of Indonesia of 2019 Number 6401, Law Number 16 of 2019, concerning Amendments to Law Number 1 of 1974 , concerning Marriage, Article 1. of selaghian and how to review Islamic law on customary sanctions of always in tribal society of Serawai in South Bengkulu.

\section{Research Method}

This type of research is field research, namely research on the practice of applying customary sanctions of selaghian on the Serawai indigenous community in Air Nipis District, South Bengkulu Regency, then reviewing the customary provisions on the application of customary sanctions of selaghian it is with Islamic law. ${ }^{12}$ The nature of this research is descriptive qualitative with the aim of obtaining exposure in systematic sentences to give a clear picture of the answers to the existing problems and provide a detailed and systematic description of the problems to be studied. Then a careful analysis will be carried out based on the field data obtained.

The research subjects in this study were the Serawai tribal community in Air Nipis District, South Bengkulu Regency, Bengkulu Province, especially the core informants (key person) namely the traditional head, village elders, village government (village head or his apparatus), religious leaders, and the community who practice selaghian based on the assumption that reality is unique, complex, and multiple. ${ }^{13}$ While the object of this research is the subject matter to be researched and analyzed, the object to be studied in this case is the implementation of customary sanctions of selaghian in the Serawai tribal community in Air Nipis District, South Bengkulu Regency, Bengkulu Province in the perspective of Islamic law.

The data used in this study consisted of

12 Gempur Santoso, Metodologi Penelitian, (Jakarta: Prestasi Pustaka Publisher, 2012), p. 30.

13 Guba \& Lincoln, Naturalistic Inquiry, (Beverly Hills: Sage Publication), 1989, p. 198. 
primary data and secondary data collected by observation and interview techniques by selecting informants purposively (directly appointed as needed). The data collected were analyzed by qualitative methods which include data reduction, display data, and conclusion drawing.

\section{Theory of Customary Law Enforcement}

There are several theories related to the application of customary law, namely: receptie in complex theory, receptie theory, receptie exit, and receptie a contrario.

Receptie in complexu theory put forward by Van Den Berg who lived from 1845 to 1927, was an expert in the field of Islamic law, who lived in Indonesia from 1870-1887. In his theory, Van Den Berg states that "Islamic law is fully applicable for Muslims, because they have embraced their religion even though in practice there are deviations". ${ }^{14}$ This theory is a formulation resulting from the struggle of Van Den Berg's thoughts after paying attention to the legal facts that occurred in Indigenous people. He conceptualized this in Stbl. 1882 No. 152 which contains provisions for the Indigenous people to apply religious law in their environment. The theoretical effect is that the colonized people (natives) who are Muslim apply Islamic law. So that the Islamic Religious Courts (the Veranda of the Mosque/Mahkamah Syariah) which existed before the Dutch came to the archipelago, their legal authority is still recognized. ${ }^{15}$ If you look at this fact, then actually Van Den Berg has contributed to the Indonesian people (Indigenous) especially for those who are

14 Sayuti Thalib, Receptio A Contrario: Hubungan Hukum Adat Dengan Hukum Islam, Cet. III, (Jakarta: Bina Aksara, 1982), p. 15

${ }^{15}$ Muh Tahmid Nur, Maslahat dalam Hukum Pidana Islam, (Diskursus Islam, Vol. I, No 2, Agustus 2013), p. 306.
Muslims, by formulating Islamic law with the theory of receptie in Complexu. He was also instrumental in the publication of Stbl. 1882 No. 152 concerning the establishment of the Religious Courts (Priesterraad) except the District Court (Landraad), which was previously preceded by the compilation of a book containing a collection of Islamic law, for judges to handle, such as Mogharrer Code in 1747, Conpendium Van Clookwijk in 1795, and Compendium Freijer in $1761 .{ }^{16}$

Receptie theory states that Islamic law applies automatically to Muslims, Islamic law applies if it has been accepted (received) by and has become their customary law. The receptie theory was originally proposed by Cristian Snouck Hurgronje, then followed and supported by Cornelis Van Volenhoven and Ter Haar. This theory is contained in chapter 134 Indiche Staatsregeling (IS) verse 2, known as the reception article. ${ }^{17}$ This theory is motivated by Snouck's desire that the Indigenous people (as the colonized people) should not hold fast to Islam. So Snouck refuted the receptie in complex theory proposed by L.W.C. Van Den Berg.

The receptie exit theory opposes the receptie theory proposed by Snouck Hurgronje, not only as long as Indonesian society was colonized by the Dutch, but continued until Indonesia was approaching independence. Indonesian legal experts pay close attention to this theory which causes Indonesian people to stay away from Islamic law. One who strongly opposes it is Prof. Hazairin in his book Seven Series of Islamic Law. Hazairin is of the opinion that after Indonesia proclaimed independence on August 17, 1945 through

\footnotetext{
16 Bustanul Arifin, Budaya Hukum Itu Telah Mati, (Jakarta: Kongres Umat Islam Indonesia, 1998), p. 2

17 Bushar Muhammad, Asas-Asas Hukum Adat, (Jakarta: Pradya Paramita, 1976), p. 57.
} 
Article 2 of the Transitional Rules of the 1945 Constitution, which stated that the Dutch Colonial inheritance law based on the receptie theory was deemed no longer valid because its spirit was contrary to the 1945 Constitution, the receptie theory must leave or (exit) because it is contrary to the Qur'an and Sunnah. Hazairin calls the receptie theory a 'Devil' theory. ${ }^{18}$

The Receptie A Contrario theory was put forward by Sayuti Thalib, which is a development of the receptie exit theory proposed by Hazairin. Sayuti Talib revealed the development of Islamic law in terms of legal politics, related to the legal politics of the Dutch colonialists while in Indonesia. The receptie a contrario theory is the opposite (con) of the receptie theory initiated by Sbouck Hurgronje. According to this theory, which literally means against (contra) the receptie theory, which states that customary law applies to Muslims if it does not conflict with Islam. Thus, the receptie a contrario theory prioritizes Islamic law over customary law, because customary law can be implemented if it does not conflict with Islamic law.

In addition to the receptie exit theory, there is also a receptie a contrario theory. This theory emerged against the background of Sayuti Talib's research on marriage and inheritance law that is currently in effect, among the points of his thoughts are as follows: For Muslims, Islamic law applies, this is in accordance with the beliefs and ideals of the law, inner ideals. and morals, as well as customary law applies to Muslims if they do not conflict with Islam and Islamic law. ${ }^{19}$

18 Mardani, "Kedudukan Hukum Islam Dalam Hukum Nasional”, Jurnal Hukum, Vol. 16 No 2, (April 2009), p. 268

19 Sayuti Thalib, Receptio A Contrario: Hubungan..., p. $15-70$.

\section{The Concept of 'Urf in Islamic Law}

'Urf etymologically is from عرف-يعرف, often interpreted as المعرف which means something known, something supreme, sequential, acknowledgment, and patience. ${ }^{20}$ 'Urfalso found in the Qur' an with the meaning "ma'ruf" which means virtue (doing good), for example in Al-Qur'an Surat al-A'raafl7: 199:

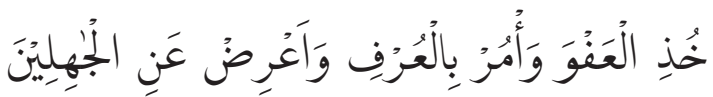
It means: "Be thou Forgiving and tell people to do what is ma'ruf".

In terminology, urf is a condition that is fixed in humans and is justified by reason and accepted by healthy character. ${ }^{21}$ Abdul Wahhab Khalaf gives the notion of urf as something that humans recognize and do, both in terms of words, actions, including what they leave behind. ${ }^{22}$

Among some Arabic linguists, there are those who equate the meaning of the word 'urf with 'adat, those two words mutaradif (synonym), after being absorbed into Indonesian it becomes "custom". According to Amir Syarifuddin, "if the two words were combined in a sentence, for example "the law is based on 'adat and 'urf'. It doesn't mean the word 'adat and 'urf it has a different meaning even though it uses the conjunction "and" which is usually used as a word that distinguishes between two words. Because the two words have the same meaning, in the example above, the word 'urf is a reinforcement for the word 'adat. ${ }^{23}$

Furthermore, Amir Syarifudin explained that the word 'urf is used by looking at the

20 Amir Syarifudin, Ushul Figh, Jilid 2, (Jakarta: Kencana Prenada Media Group, 2011), p. 387.

${ }^{21}$ Ahmad Fahmi Abu Sunnah, Al-'Urf wa al-Adah Fi Rayi al-Fuqaha', (Kairo: Dar al-Basair, 2004), p. 28.

${ }^{22}$ Abdul Wahhab Khalaf, 'Ilmu Ushul al-Figh, (Mesir: Dar al-Qalam, 1978), p. 89.

${ }^{23}$ Amir Syarifudin, Ushul Fiqh..., p. 387. 
quality of the actions carried out which are recognized, known and accepted by many people, therefore the word urf has a good connotation. As the definition formulated by Badran, quoted by Amir Syarifuddin, namely "whatever is accustomed and followed by many people, either in the form of words or deeds, is done repeatedly so that it leaves an imprint on their souls and is well accepted by their common sense". ${ }^{24}$ Amir Syarifuddin also explained the opinion of Mustafa Syalabi, who stated that: the difference between 'urf and 'adat, does not see the difference between the two words in terms of the connotation of content as described in artas, but in terms of the scope of their use. The word 'urf is always used to always be used for the congregation or group. While the word 'custom' can be used for some people, in addition it also applies to groups. What has been done (becomes a habit) of a person, then that action can be referred to as the 'custom of the person who does it but cannot be said to be 'urf that person. ${ }^{25}$

In terms of object, 'urf is divided into 'urf qauli and 'urf fi'li. 'Urf qauli is a certain term given by a community to give a certain meaning, and there is no tendency for other meanings, so that meaning can be understood and comes to mind). ${ }^{26}$ while 'urf fi'li is a habit that applies in certain jobs or activities that are usually carried out continuously, so that it is seen as a social norm, whether it is in the form of al-amal al-'adiyah (habits) for example the habit of taking cigarettes at each other. between friends without any words of asking or giving, is not considered

${ }^{24}$ Amir Syarifudin, Ushul Figh..., p. 388.

${ }^{25}$ Amir Syarifudin, Ushul Fiqh..., p. 389.

26 Sunan Autad Sarjana dan Imam Kamaludin Suratman, "Konsep 'Urf dalam Penetapan Hukum Islam”, TSAQAFAH, Vol. 13, No. 2, November 2017, p. 286 stealing. Or civil muamalah such as buying and selling without consent (bai'nu'atah), is a commonplace and common thing among the people, but with the provision that only goods with a small nominal price. ${ }^{27}$

In terms of the scope of its use, 'urf is divided into 'urf 'amm (generally applicable habits) and typical urf (specifically applicable habits). ${ }^{28}$ As for in terms of its validity in the perspective of syara', then 'urf is divided into urf shahih (customs that are in accordance with the shari'a) and 'urf fasid (habits that are not in accordance with the shari'a). ${ }^{29}$ In general, 'urf is practiced by all figh scholars, especially among the Hanafi and Malikiyah scholars. ${ }^{30}$ For the position of 'urf as one of the benchmarks of law, the fuqaha vary in holding it as a legal argument. Imam asSuyuti returns its application to the rules, العادة (the custom is a legal consideration). ${ }^{31}$ In order for 'urf to be accepted to be practiced and used as legal istinbath, it must meet the requirements, namely it must be of benefit and acceptable to common sense, generally applicable and evenly distributed among people who are in the environment, already existing (applicable) at that time. , not 'urf which appears later, and does not contradict and neglect the existing syara' arguments or contradict certain principles. ${ }^{32}$ Asy-Syatibi emphasized that custom must rely on maslahah. That is, the good or bad practice of a custom depends on the elements of maslahat and mafsadat. If in the practice of a custom, the maslahat element is greater than the mafsadat element, then the custom

\footnotetext{
${ }^{27}$ Amir Syarifudin, Ushul Fiqh..., p. 391.

${ }^{28}$ Amir Syarifudin, Ushul Fiqh..., p. 391.

${ }^{29}$ Amir Syarifudin, Ushul Fiqh..., p. 393.

${ }^{30}$ Amir Syarifudin, Ushul Fiqh..., p. 399.

${ }^{31}$ Amir Syarifudin, Ushul Fiqh..., p. 400.

${ }^{32}$ Amir Syarifudin, Ushul Fiqh..., p. 402.
} 
is a good custom (al-'addah shahihah). On the other hand, if the mafsadat element is greater than the maslahat, then the custom is a bad custom (al-'addah al-fasidah) which must be rejected. ${ }^{33}$

\section{Sanction System in Islamic Law}

Sanctions or uqubat are set to prevent humans from committing crimes as the word of Allah SWT. in the Qur'an Surah alBaqarah/2: 179:

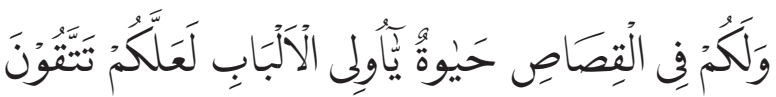

Meaning: "And in qishaash there is (guaranteed continuity) life foryou, Opeople of understanding, so that you may become pious"

The word guarantee of survival means protecting the soul and preserving people's lives, not the life of the perpetrator because after committing a murder, the perpetrator will be subject to qishash or the death penalty for him. Because when people see the qishash sanction imposed on the perpetrator, then as human beings with common sense of course they will not imitate the actions of the perpetrator if they do not want to get the same sanction. So that there is a guarantee for the protection of the human soul and the preservation of community life. ${ }^{34}$

Islam views that crime is not something that naturally exists in humans. This means that a criminal cannot make excuses by saying that he committed a crime because he is already a descendant and it is his nature because his father and mother are criminals. Crime is also not a profession that human

${ }^{33}$ Muhammad Khalid Mas'ud, Islamic Legal Philosopy, A Study Abu Ashaq as-Syatibi's Life and Thought, Alih Bahasa Ahsin Muhammad, (Bandung: Pustaka, 1996), p. 314

34 Ahmad Hanafi, Asas-Asas Hukum Pidana Islam, (Jakarta: PT. Bulan Bintang, 1990), p. 27 endeavors, because Allah SWT. created humans complete with His rules in shari'a law' so that by using their reason humans can see jobs or professions that are in line with syara' law and professions that are contrary to syara' law. Therefore, the thief can't justify saying that he was forced to steal because he had to feed his family

Islamic law emphasizes that the perpetrators of crimes must not only be punished in this world, but in the hereafter he will also receive sanctions from Allah SWT. As some of the words of Allah swt. One of them in Surah $\operatorname{ar-Rahmaan/55:~41,~namely:~}$

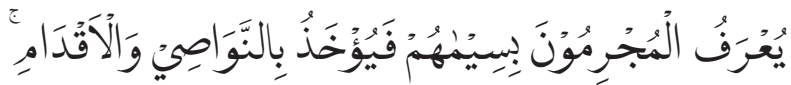
Meaning: "Those who have sinned are known by their signs, then their heads and their feet are grabbed."

The purpose of sanctions in Islamic law is jawabir and zawajir, i.e. the perpetrator of the crime must be recompensed according to what he has done regardless of whether the punishment is beneficial to himself or the community. Zawajir is a type of punishment that aims to awaken the perpetrators of crime (jarimah) so that they do not repeat the crimes they have committed, and this punishment is also a lesson for others not to commit similar crimes. ${ }^{35}$ The forms of sanctions in Islam include: hudud, qishash-diyat, and ta'zir. ${ }^{36}$

The word hudud is a compound word from al-Haddu which means control or prevention. ${ }^{37}$

35 Toha Andiko, "Reinterpretasi Sanksi Pidana Islam (Studi Terhadap Pemikiran Prof. KH. Ibrahim Hosen, LML)", Madania, Vol. XVIII, No. 2, (Desember 2014), p. 236.

${ }^{36}$ H. A Djazuli, Figh Jinayah (Menanggulangi Kejahatan Dalam Islam, (Jakarta: PT. Raja Grafindo Persada, 2016), p. 12.

37 Ahmad Marson Munawwir, Kamus al-Munawwir Arab-Indonesia Terlengkap, (Yogyakarta: Pustaka Progrssif, 2001), p. 262. 
While qishash-diyat is a form of punishment for perpetrators of crimes against the soul (killing life) and limbs (injury). ${ }^{38}$ As for ta'zir, it means educating and improving the perpetrator so that he is aware of his actions and then leaves and stops it. ${ }^{39}$

\section{Traditional Practice of Selaghian}

Selaghian comes from the word laghi which is added by the prefix se- and the suffix -an. The word laghi (in Serawai) is the same as the word "run/lari" in Indonesian. If you add the prefix se and the suffix an, then the word selaghian is the same as the word selarian. However, the word selarian is not a standard word in Indonesian. Therefore, the word selaghian cannot be interpreted with the word selarian. In the Customary Law of the Institutions of the Nine Onderafdelingen in the Bengkulu Residency, the word selaghian is discussed with the word run and run. ${ }^{40}$ In the customary law of this institution, it is stated that the meaning of escaping is to bring a woman or randa to the house of the penghulu king with the intention that the man who brings it is married to the woman who is taken away. ${ }^{41}$ While in UndangUndang Simbur Cahaya, the word selaghian means taking away/melarikan. ${ }^{42}$ Some researchers and writers on Serawai tribal customs sometimes use the word selaghian with the word elopement. ${ }^{43}$ However, the word elopement is a universal term that is

\footnotetext{
${ }^{38}$ Makhrus Munajat, Hukum Pidana Islam..., p. 165.

${ }^{39}$ Makhrus Munajat, Hukum Pidana Islam..., p. 178.

${ }^{40}$ Ki Agoes Hosen, Kumpulan Undang-Undang..., p. 89.

${ }^{41}$ Ki Agoes Hosen, Kumpulan Undang-Undang..., p. 16.

${ }^{42}$ L. W. C. Van Den Berg, , Rechtsbronnen Van ZuidSumatra, Uitgegeven, Vertaald En Toegelicht, (Delft: Brill, 1894), p. 267.

${ }^{43}$ Musiardanis, Kelompok-Kelompok Suku Bangsa Di Provinsi Bengkulu, ( https://warisanbengkulu.blogspot. com/2011/04/bangsa-adat-dan-kebudayaan-bengkulu. html), Accessed on June 13, 2021, 22:59 WIB.
}

known by the Indonesian people in general and is sometimes interpreted connotatively. ${ }^{44}$ The meaning of the term elopement differs in each region, for example elopement in the Serawai Tribe community in Air Nipis District, South Bengkulu Regency is called elopement/selaghian which has its own meaning and procedure.

According to the Chairman of the Customary Deliberation Board (BMA) Air Nipis Sub-district, selaghian is the departure of a man and a woman to the village where the man lives (the house of the head of the village, the house of male relatives, and or the house of male parents) either each brings a friend or does not bring a friend, with the woman's parents not knowing, who has the purpose of getting married. Selaghian is divided into 2 forms, namely selaghian maling diri and selaghian sebambangan. Selaghian maling diri is, always bringing friends, men bring one bachelor friend and women bring one girl friend. Meanwhile, Sebambangan selaghian is underhand selaghian, there are no witnesses, men and women each do not bring friends. Of the two forms of selaghian, the woman (the girl who is dilaghikan) leaves a message to her parents with the aim that the parents can know that she (daughter) is selaghian. The message can be conveyed through a neighbor of the woman's parent's house, a friend of the woman or by letter (usually the letter is placed in a rice storage area with the aim of making it known to her parents quickly). ${ }^{45}$ For example, what Melati (not her real name) (Maras Village)

${ }^{4}$ Azhar Afaf Hanifah, dkk, Makna Dan Eksistensi Sebambangan Di Kalangan Muslim Desa Canggu, Kalianda Lampung Selatan, (https://stainutmg.ac.id/ wp-content/uploads/2019/05/5.-Univ.-Sebelas-MaretSurakarta-Azhaar-Afaf-Hanifah-Prosiding.pdf), Accessed on July 14, 2021, 00:23 WIB

45 Personal interview with Sairi (Chairman of BMA Air Nipis District), Air Nipis, 25 June 2021. 
did when she visited Suka Negeri Village with a man named Buyung (not her real name) Melati left a message from her friend next door:

"Waktu aku selaghian mpaini aku nitipkah pesan ngan Sinta jemau iligh ghumah kami tu, aku kiciakkah ngan sinta tulung kiciakkah ngan mak kami amun lah petang kelau, aku selaghian ngan Buyung jemau dusun Suka Negeri anak Herman (bukan nama sebenarnya)". ${ }^{46}$

(When I was in the past, I left a message to Sinta, the neighbor next door, I said that if it was late, please tell my mother, I was always with Buyung, a villager from Suka Negeri, Herman's son).

Selaghian what people still do today in general is only selaghian sebambangan. This is due to the circumstances behind the selaghian. In the past, this was generally done because the parents did not approve of their child's marriage plan with her future husband. While nowadays selaghian is generally carried out by teenagers under the age of marriage. ${ }^{47}$ Of the 17 cases presented by Mr. Sairi consisting of 2 cases of children still attending the junior high school level and the remaining 15 cases of children aged at the senior high school level. ${ }^{48}$ For example what Melati and Buyung did above, Buyung is only 17 years old while Winda is only 16 years old. They are always motivated by things that they themselves do not want, as revealed by Melati, when interviewed:

"Kami selaghian mpaini sebenarau kerenau ketepaksauan, kami masiah SMA, mak ngan bak kami lum ngajuang nikah tapi tuapau

46 Personal interview with Sairi (Chairman of BMA Air Nipis District), Air Nipis, 27 June 2021

${ }^{47}$ Personal interview with Sairi (Chairman of BMA Air Nipis District), Air Nipis, 25 June 2021

${ }^{48}$ Personal interview with Sairi (Chairman of BMA Air Nipis District), Air Nipis, 25 June 2021 namaunyau mungkin lah takdir, maluan dikiciakkah madak didehgan amu kediau, kami ndiak pacak ndiak nikah waktu ini, ahirau kami beduau ngan santingan aku selaghian" ${ }^{49}$

(We used to do selaghian, actually because of compulsion, we were still in high school (SMA), our parents didn't allow us to get married, but maybe because it was fate, it was actually embarrassing to say and uncomfortable to hear, both of us couldn't help but have to married at that time (this answer indicates, that they were pregnant out of wedlock), we finally chose the path to selaghian).

The background to the occurrence of selaghian due to pregnancy out of wedlock like this also occurs to the 18-year-old Tono (not real name) (Maras Village) couple with 16-year-old Aminah ( Darat Sawah Village) as revealed by Tono in an interview:

"Anu dang aku selaghian ni mpaini, tuapau amu akuni agak nakal nidau belagham luak jemau, yak tuapau bekawan dengan tinau, akbirau kami nidau pacak nidau agi arus nikah waktu itulah. Kami ndiak beghani dengan mak bak kami ndak ngiciak iluakiluak tuapau kami ni masiah keciak galau, mbak disau lum ndiau iluak nikah, tapi tuapau karenau keadaan tadi, ahirau kami selaghian ngan bini aku mbak ini tu". 50

(Like this Dang [call for researcher] I used to do selaghian, I was a rather naughty child not a diligent child like people, I made friends with women, finally one day, we couldn't help but have to get married right then and there, neither of us dared say this to our parents because we are not yet fit for marriage, but what can we do because of this situation we finally choose to do selaghian).

49 Personal Interview With Tono, Maras, 27 June 2021.

50 Personal Interview With Tono, Maras, 27 June 2021. 
The place to go for selaghian in the Serawai people is not like elopement in general (the man and woman flee from the village (region) where they live to another place with the aim of living together or getting married). ${ }^{51}$ There are 3 (three) places to go, namely to the house of the penghulu (syariah administrator / priest and khatib), to the house of a male relative who is in the same village as the man's parents, and to the house of the male parent. ${ }^{52}$

As for the place to go for selaghian, nowadays there are no more people who go to the house of the imam, preacher, and male relatives. Based on information from the head of BMA, Air Nipis Sub-district, the usual place for the male and female pair is to go to the house of the man's parents. ${ }^{53}$ As the couple Winda Nabela and Rosi Rizki above did, they went to Rozi's parents' house in Suka Negeri Village.

After 2 (two) days of selaghain, the woman's family sends a messenger to the man's family (selghian's place) to confirm whether their daughter is really in the house according to the message given to the woman's parents. The delegates sent were 3 (three) people, namely 2 (two) kerebai (married women) and 1 (one) girl. When the female envoy arrives at the male parent's house, the envoy will ask the male family a question "adau nidau kamu bemendah si a (gadis yang dilaghikah)"? (Meaning: do you (male family) welcomed guests (daughter)?)). The male family will answer with an answer "au adau, lah duau malam diau ni di sini" (meaning: yes there is, she (daughter) has been here for two nights). Then the female family envoy will ask again "tuapau tujuan

${ }^{51}$ Personal Interview with Sairi (Chairman of BMA Air Nipis District), Air Nipis, 25 June 2021.

${ }^{52}$ Ki Agoes Hosen, Kumpulan Undang-Undang..., p. 91.

${ }^{53}$ Personal Interview with Sairi (Chairman of BMA Air Nipis District), Air Nipis, 25 June 2021. diau kebadah kamu ni?" (means: what is the purpose of him going to your place (the male family). The male family will answer "diau laghi, kebadah kami ini betujuan ndak bekeluarga, tau au ni anak aku"( meaning: he went to our place with the aim of having a family (marrying) with my child). Next the female envoy will say "jadi amun luak itu ceritaunyau, kapau dighi beghilighan (it means: okay then the story is, we ask the family of the male side to go downstream (if the place where the male kai lives is upstream) or kapau dighi beghuluan (means: go upstream, (if the male residence is downstream) malam pagi ke luak manau rasan diau duau ini". ${ }^{54}$ (meaning: tomorrow night we will solve the problem of these two children).

After this question and answer, the woman's envoy will say goodbye to go home with the woman's friend selaghian (if the woman brings a friend). After arriving at the woman's house, the messenger will convey the information that their daughter is indeed at the man's house in the message received by the woman's parents earlier. In addition, the envoy also told the results of their conversation with the male family.

On the following night the male family sent a messenger to the female family to fulfill the promise, which had been agreed upon when the female envoy came to the male party's house earlier. The number of envoys sent by men is not specifically regulated in terms of the number and social status, it's just that the people sent are generally men. After arriving at the house of the woman's family, the envoy will first apologize to the woman's family because their son has neglected their daughter. They also conveyed to the woman's family that their daughter was not wasted, the

${ }^{54}$ Personal Interview with Sairi (Chairman of BMA Air Nipis District), Air Nipis, 25 June 2021. 
girl was given a proper place and good food. Furthermore, the woman's family will answer that they are very grateful for what the boy's family has done for their daughter (while at the boy's house). After conveying their apologies and conveying that their daughter was not wasted, this envoy will convey their intentions and their next goal, namely to merisau rasan (the event of determining the day and date of the marriage contract and wedding party) bachelors and girls who did selaghian. ${ }^{55}$

The process of merisau rasan for those who did selaghian equals to merisau rasan those who did not do selaghian, namely the process of determining the day, date and place of the marriage contract and the wedding party will be held. Both for the day and date at the woman's house as well as the day and date at the man's house. ${ }^{56}$

After merisau rasan, then the woman's family will submit a request to the man to take their daughter back to her parents' house. The day to take the daughter home is according to the agreement of the two parties, it can be the next day or the following day according to the agreement. The person who took the girl home consisted of 2 (two) kerebai from the male side. Even though the girl has been brought home, if the man needs the girl before the day of the marriage contract and the wedding party (usually to go on pilgrimages, etc.), then the man is allowed to pick her up. The person who picks him up is not specifically regulated in their customs, it can be male parents and/ or male relatives. Even now, it is possible for the man who is the woman's future husband to pick her up. ${ }^{57}$

\footnotetext{
55 Personal Interview with Sairi (Chairman of BMA Air Nipis District), Air Nipis, 25 June 2021.

56 Personal Interview with Sairi (Chairman of BMA Air Nipis District), Air Nipis, 25 June 2021.

57 Personal Interview with Sairi (Chairman of BMA Air Nipis District), Air Nipis, 25 June 2021.
}

After merisau rasan, the next process will be the same as the marriage process in general (not selaghian), the marriage contract is carried out according to the religion they profess, as well as the wedding ceremony in accordance with existing customs in general.

Process after process has been passed and has even reached the stage merisau rasan (determination of the day and date of marriage) is not the slightest mention of the issue of sanctions (fines) of selaghian. The sanction of selaghian is regulated in such a way by custom, both past and present customary rules. Penalty of selaghian. Some of the things done by indigenous peoples in the past are contained in the Simbur Cahaya Law and the Institutional Customary Law. Inside the Simbur Cahaya Law of selaghian called melarikan. ${ }^{58}$ The sanction of selaghian in this Law it is stated in articles 79 and 80 which read as follows: ${ }^{59}$

Article 79: If the bachelor runs away from the girl, the bachelor is subject to a fine of 6 (six) riyals, then at that time the single girl is married off, in 6 (six) riyals, one riyal goes home on a pesirah, three riyas, and two riyas to the owner.

Article 80: If randa is taken away by a man, he is subject to a fine of three riyals, then at that time the randa/widow is married to the man who ran away, the fine is divided by one riyal on the pesirah, one riyal on the pruatin, one riyal on the holder.

Sanctions in the Simbur Cahaya Law are not explained in the form of sanctions based on type selaghian (sebambangan and maling diri). In this Act, it is only explained based on

${ }^{58}$ L. W. C. Van Den Berg, , Rechtsbronnen Van ZuidSumatra, Uitgegeven, Vertaald En Toegelicht, (Delft: Brill, 1894), p. 267

${ }^{59}$ L. W. C. Van Den Berg, , Rechtsbronnen Van ZuidSumatra, Uitgegeven, Vertaald En Toegelicht, (Delft: Brill, 1894), p. 268 
who is being taken away. Meanwhile, in the Institutional Customary Law, the following sanctions are stated, namely: ${ }^{60}$

1. Melarikan maling diri, namely men and women who were rushed there bringing one friend each. It is wrong to be punished, if the girl who is taken away is fined by both parties, $f$ 12.00, if randa (widow) is $\mathrm{f} 6.00$, and if it is someone's fiancee, f 24.00, the wrong person must be married.

2. Melarikan sebambangan, ie dark escape with no witnesses or friends. It's wrong to be punished, if the girl who is taken away is fined by both parties, f 24.00, if randa f 12.00 , and if the fiancee is $\mathrm{f} 48.00$, after all, it's the person's fault, they must be married off.

In the case of imposition of sanctions (fines) the selaghian who bear the burden are the parents/guardians of the male (bachelor) and female (girl) side, not the one who performs the selaghian (bachelor and girl). This sanction is imposed on their parents because according to custom, the occurrence of the selaghian is a form of the parents' failure in educating (directing) their children. This causes their children to do things that are prohibited by custom. The provision of sanctions (fines) according to custom is a form of learning (rebuke) to parents, both parents whose children are doing selaghian so that it does not happen again to other children (not married) and also to other parents (who have unmarried children) so that their children do not practice selaghian. ${ }^{61}$

\section{Selaghian Customary Sanctions From an Islamic Law Perspective}

In analyzing whether the imposition of selaghian sanctions on the Serawai Tribe

\footnotetext{
${ }^{60}$ Ki Agoes Hosen, Kumpulan Undang-Undang...,p. 80

${ }^{61}$ Personal Interview with Sairi (Chairman of BMA Air Nipis District), Air Nipis, 25 June 2021.
}

community in Air Nipis District is a good custom (al'adah al-shahihah) and acceptable in Islamic law or vice versa, including a bad custom (al'adah al-fasidah), there are three indicators that are used as guidelines in analyzing it. First, the analysis is based on the custom itself ( $u r f$ ), whether the custom is a good urf or vice versa. Second, the analysis is based on the theory of punishment, whether it includes the type of punishment hudud, qishas, or ta'zir. Third, based on the purpose of giving punishment (philosophy of law), whether it is in accordance with the purpose of giving punishment in Islamic law or vice versa.

Customs that apply in the midst of society, by Islam serve as a means of development in the Islamic legal system. This is due to several things, adat has proven to be very effective in resolving cases for which concrete answers are not found in the Qur'an or the Prophet's Hadith. ${ }^{62}$ Therefore, custom is one of the sources of Islamic law that must be considered in every process of creating Islamic law.

However, not all customary practices can be simply adopted as part of Islamic law. This is because, the customs that develop in the midst of society, there are good customs (al-'adah al-shahihah) and there are also bad customs (al-'adah al-fasidah). In the theory of the formation of Islamic law, only good customs can be accepted, while bad customs must be rejected. ${ }^{63}$ In this context, the jurists formulate various legal rules related to customs, such as al-adah al-muhakkamah (customs can be made into law). ${ }^{64}$

\footnotetext{
${ }^{62}$ Ratno Lukito, Pergumulan Antara Hukum Islam dan Hukum Adat di Indonesia, (Jakarta: INIS, 1998), p. 6.

63 Umar Syihab, Hukum Islam dan Transformasi Pemikiran, (Semarang: Bina Utama, 2006), p. 32.

${ }^{64}$ Nasrun Harun, Ushul Figh, (Jakarta: Logos, 2016), p. 141 .
} 
A good custom is a custom that does not conflict with the syara' arguments, and does not justify what is unlawful and does not abort obligations. While bad custom is the opposite. ${ }^{65}$ Meanwhile, Subhi Mahmassani stipulates in detail the conditions for the acceptance of a custom, which are as follows: ${ }^{66}$

a. Customs must be accepted by good character, that is, they can be accepted by reason and in accordance with sane feelings or with public opinion;

b. Things that are considered customary must happen again and again;

c. What is considered valid for mu'amalat deeds are old customs, not the last;

d. A custom cannot be accepted if between two parties there are excessive conditions;

e. Customs can only be used as legal reasons if they do not conflict with the provisions of nash.

Meanwhile, al-Syatibi emphasized that custom must rely on maslahah. That is, the good or bad practice of a custom depends on the elements of maslahat and mafsadat. If in the practice of a custom, the maslahat element is greater than the mafsadat element, then the custom is a good custom (al-'adah shahihah). On the other hand, if the mafsadat element is greater than the maslahat, then the custom is a bad custom (al-'adah al-fasidah) which must be rejected. ${ }^{67}$

Based on the three views above, it can be concluded that an adat can be accepted

${ }^{65}$ Abdul Wahhab Khallaf, Ushul Figh, (Beirut: Dar al-Fikr, 1978), p. 89.

${ }^{66}$ Sobhi Mahmassami, Falsafat at-Tasyri Fi al-Islam, Alih Bahasa Ahmad Sudjono, Cet. 1, (Bandung: PT. alMa'arif, 1976), p. 262-264.

${ }^{67}$ Muhammad Khalid Mas'ud, Islamic Legal Philosopy, A Study Abu Ashaq as-Syatibi's Life and Thought, Alih Bahasa Ahsin Muhammad, (Bandung: Pustaka, 1996), p. 314 . as part of Islamic law, with at least two conditions. First, it does not conflict with the syara' texts which have explicitly stipulated a legal provision. Second, the custom must have more maslahat than mafsadat. This framework of thought in practice must be guided in solving problems of Muslims related to customs.

From the description above, it can be concluded that the custom of giving selaghian sanctions to the Serawai community in Air Nipis District, South Bengkulu Regency, is a good custom (al-'adah shahihah). Because basically, selaghian is an act of approaching adultery (in Islamic teachings) namely taking a girl (woman) who is not a mahram to someone else's house, without the permission of the woman's parents (guardian). That is, the provision of selaghian sanctions is in line with the verses of the Qur'an Surah al-Isra ‘17: 32, لاتنقبوا الزنى (and do not approach adultery).

When faced with three forms of punishment in Islam, namely hudud, qishash-diyat, and ta'zir, then the imposition of selaghian sanctions on the Serawai Tribe community in Air Nipis District is a type of tazir punishment. Because the imposition of selaghian sanctions on the Serawai indigenous people is not a violation of God's rights or human rights. Rather, it is a violation of adat, for which the authority to administer sanctions is given to the village head (Leader). This is in accordance with the ta'zir punishment which is also not a violation of God's rights or human rights, but acts that can damage the peace and peace of society (immoral acts or crimes that do not include hudud and qishas). The level of punishment given is also not explained in the verses of the Qur'an or hadith, but is based on customary customs that generally apply to the local community. This is in line with the 
ta'zir law, where the level (form, amount) of the punishment is determined by the judge (who is authorized to give punishment) based on the form of the error (violation) committed. In addition, the purpose of imposing sanctions for selaghian perpetrators is to provide a deterrent effect (education) for perpetrators and other communities not to commit selaghian, because selaghian is a disgraceful act and can cause slander (bringing girls/women to spend the night at someone else's house without permission). The woman's parents/guardians) for customs and society, even though it is in the context of getting to the level of marriage. This is in line with the notion of ta'zir punishment itself as stated by Abdul Qadir Audah and Wahbah Zuhaily. Tazir is defined as al-man'u wa radd, because he is able to prevent the perpetrator from repeating it. It is interpreted as ta'dib because tazir is intended to educate and improve the perpetrator so that he is aware of his actions then leaves and stops it. ${ }^{68}$

Based on the purpose of the sanctions, the imposition of these sanctions is aimed at providing lessons to the perpetrators and the general public not to commit selaghian. Because selaghian is a disgraceful act, both according to custom and in the view of Islamic law, because it belongs to the category of approaching adultery. So the imposition of sanctions is in accordance with the purpose of giving sanctions in Islamic law, namely as a function of providing a deterrent effect (zawajir).

\section{Conclusion}

From the results of the research and discussion above, it can be concluded: first, the practice of selaghian that is still carried out

${ }^{68}$ Makhrus Munajat, Hukum Pidana Islam..., p. 178. by the Serawai Tribe community in Air Nipis District is selaghian sebambangan, namely selaghian performed by both partners (male and female) with each don't bring friends. This case will be given a sanction (fine) by custom, namely if the girl runs away the fine is IDR 250,000.00 (a total of 17 cases were found in 2020), if the randa is fined IDR $150,000.00$ (no case is not found), if the fiancé is the person the fine IDR 500.000,00 (no cases found). Second, the review of Islamic law on the customary sanction of selaghian on the Serawai Tribe community in Air Nipis District, South Bengkulu Regency is included in 'urf sabih, because the imposition of such sanctions does not conflict with the syara' arguments. In terms of its type, including the type of tazir punishment, on the basis of having been alone between a man and a woman who is not a mahram (khalwat ajnabiyah), so it is feared that adultery will occur. In addition, the imposition of selaghian sanctions on the Serawai indigenous people is not a violation of God's rights or human rights, but a violation of customs. The form and amount of punishment given is also not explained in the verses of the Qur'an or Hadith, but based on customary customs that generally apply to the local community. So this is in accordance with the ta'zir punishment which is also not a violation of God's rights or human rights, and the form or amount of the punishment is determined by the judge (who is authorized to give punishment) based on the form of the error (violation) committed. In addition, the purpose of imposing sanctions for selaghian perpetrators is to provide a deterrent effect (as a function of zawajir) for selaghian perpetrators. This is in line with the purpose of ta'zir punishment itself, which is to educate and improve the perpetrator, so that he becomes aware of his actions and then leaves and stops them. 


\section{References}

Andiko, Toha. "Reinterpretasi Sanksi Pidana Islam (Studi Terhadap Pemikiran Prof. KH. Ibrahim Hosen, LML)", Madania, Vol. XVIII, No. 2, Desember 2014.

Apriyani, Rini. "Keberadaan Sanksi Adat Dalam Penerapan Hukum Pidana Adat", Jurnal Hukum Prioris, Vol. 6, No. 3, 2018.

Arifin, Bustanul. Budaya Hukum Itu Telah Mati, Jakarta Kongres Umat Islam Indonesia, 1998.

Azhar, AfafHanifah, dkk. "Makna Dan Eksistensi Sebambangan Di Kalangan Muslim Desa Canggu, Kalianda Lampung Selatan”, (https://stainutmg.ac.id/wp-content/ uploads/2019/05/5.-Univ.-Sebelas-MaretSurakarta-Azhaar-Afaf-Hanifah-Prosiding. pdf)

Berg, L. W. C. Van Den. Rechtsbronnen Van Zuid-Sumatra, Uitgegeven, Vertaald En Toegelicht, Delft: Brill, 1894.

Dewi, Satiya Citra, Hasanuddin Yusuf Adan. "The Effectiveness of Adat Sanction for Khalwat Offense based on Islamic Criminal Law in Ketol, Central Aceh", Legitimasi: Jurnal Hukum Pidana dan Politik Hukum, Vol. 10, No. 2, 2021.

Djazuli, A. Fiqh Jinayah (Menanggulangi Kejahatan Dalam Islam, Jakarta: PT. Raja Grafindo Persada, 2006.

Fahimah, Iim. "Akomodasi Budaya Lokal (Urf) dalam Pemahaman Fikih Ulama Mujtahidin”, Jurnal Ilmiah Mizani, Vol. 5, No. 1, 2018

Guba \& Lincoln. Naturalistic Inquiry, Beverly Hills: Sage Publication, 1989.

Hanafi, Ahmad. Asas-Asas Hukum Pidana Islam, Jakarta: PT. Bulan Bintang, 2000.

Harun, Nasrun. Ushul Fiqh, Jakarta: Logos, 2006.

Hilman. Hukum Pidana Syariat Islam Menurut Ajaran Ahlus Sunnah, Jakarta: Bulan Bintang, 2000 .

Hosen, Ki Agoes. Kumpulan Undang-Undang
Adat Lembaga Dari Sembilan Onderafdelingen Dalam Keresidenan Bengkulu, Jakarta: Proyek Penerbitan Buku Bacaan Sastra Indonesia dan Daerah, 1985.

Khallaf, Abdul Wahhab. 'Ilmu Ushul al-Fiqh, Mesir: Dar al-Qalam, 1978.

Law Number 16 of 2019 concerning Amendments to Law Number 1 of 1974 concerning Marriage.

Lukito, Ratno. Pergumulan Antara Hukum Islam dan Hukum Adat DI Indonesia, Jakarta: INIS, 1998.

Mahmassami, Sobhi, Falsafat at-Tasyri' Fi alIslam, Bandung: PT. Al-Ma'arif, 1976.

Mardani. "Kedudukan Hukum Islam dalam Hukum Nasional", Jurnal Hukum Vol. 16, No. 2, April 2009.

Mas'ud, Muhammad Khalid, Islamic Legal Philosopy, A Study Abu Ashaq as-Syatibis Life and Thought, Alih Bahasa Ahsin Muhammad, Bandung: Pustaka, 1996.

Muhammad, Bushar. Asas-Asas Hukum Adat, Jakarta: Pradya Paramita, 1976.

Musiardanis, Kelompok-Kelompok Suku Bangsa Di Provinsi Bengkulu, https://warisanbengkulu. blogspot.com/2011/04/bangsa-adat-dankebudayaan-bengkulu.html),

Nur, Muh Tahmid. "Maslahat dalam Hukum Pidana Islam”, Diskursus Islam, Vol. 1, No. 2, Agustus 2013.

Santoso, Gempur. Metodologi Penelitian, Jakarta: Prestasi Pustaka Publisher, 2012.

Sunnah, Ahmad Fahmi Abu. Al-'Urf wa al-Adah Fi Ra'yi al-Fuqaha', Kairo: Dar al-Basair, 2004.

Suparlan, Elon. "Pelaksanaan Sanksi Adat Bagi Pelaku Zina Di Kecamatan Seluma Utara Kabupaten Seluma Perspektif Hukum Islam", Qiyas: Jurnal Hukum Islam dan Peradilan, Vol. 3, No. 2, 2018.

Suratman, Sunan Autad Sarjana dan Imam Kamaludin, "Konsep 'Urf dalam Penetapan Hukum Islam”, Tsaqafah, Vol. 13, No. 2, November 2017. 
Syarifuddin, Amir. Ushul Figh, Jilid 2, Jakarta: Kencana Prenada Media Group, 2011.

Syihab, Umar. Hukum Islam dan Transformasi Pemikiran, Semarang: Bina Utama, 2006.
Thalib, Sayuti. Receptio A Contrario: Hubungan Hukum Adat Dengan Hukum Islam, Cet. ke-3, Jakarta: Bina Aksara, 1982. 